\title{
Sources and select bibliography
}

\section{Interviews/correspondence}

Over the years, the following generously granted interviews, engaged in correspondence or both: David Andrews, Conor Brady, John Brophy, Maureen Brown, Tim Pat Coogan, James Downey, Vincent Doyle, Jim Eadie, Brian Fallon, Ronan Fanning, Douglas Gageby, Patrick Geary, Paul Gillespie, Renagh Holohan, John Horgan, Michael Keane, Richard Keatinge, John Kelly, Dennis Kennedy, Geraldine Kennedy, Joe Kennedy, Hugh Lambert, Dorothy MacGabhann, Mary Maher, Brendan Malin, Seamus Malin, Frank McDonald, Michael Mills, Gerry Mulvey, Donal Nevin, Mildred O’Brien, Barry O’Kelly, Louis O’Neill, Emily O’Reilly, Mary O'Rourke, Cathal O’Shannon, Etain O Siochain, Michael O’Toole, Andy Pollak, Don Reid, Lorna Siggins, Michael Viney, Jim Walsh, Andrew Whittaker, Pádraig Yeates.

\section{Archival sources}

Chris O'Sullivan Audio Interview (National Library of Australia)

Conor Cruise O’Brien Papers (UCDA)

Desmond Ryan Witness Statement (Bureau of Military History)

Douglas Gageby Papers (Historic Collections Research Centre [HCRC])

Éamon de Valera Papers (UCDA)

Frank Gallagher Papers (National Library of Ireland [NLI])

John Charles McQuaid Papers (Dublin Diocesan Archives)

Joseph Dennigan Papers (UCDA)

Michael Knightly Witness Statement (Bureau of Military History)

Michael O'Toole Papers (HCRC)

NUJ Papers (HCRC)

Patrick Barry Moloney Papers (UCDA)

Piaras Béaslaí Papers (NLI)

Piaras Béaslaí Witness Statement (Bureau of Military History)

R. M. Fox Papers (NLI)

T. R. Harrington Papers (National Archives of Ireland)

William O’Brien Papers (University College Cork Library Special Collections)

\section{Government publications}

Dáil Éireann Debates and Seanad Éireann Debates

Report of the Commission to Inquire into Child Abuse (2009) 
Report of the Commission of Investigation into the Catholic Archdiocese of Dublin (2009)

\section{Trade periodicals}

An Glór, Bulletin, The Irish Journalist, Newspaper Press Directory and Advertisers' Guide

\section{Newspapers and periodicals}

The Bell, Connacht Tribune, Daily Express (Dublin), Daily Mirror (London), Evening Herald, Evening Mail, Evening Press, Freeman's Journal (Dublin), Freeman's Journal (Sydney), Glasgow Herald, The Guardian, Hibernia, History Ireland, In Dublin, Irish Catholic, Irish Echo, Irish Independent, Irish Press, Irish Times, Irish Weekly Independent, Kerry's Eye, The Kerryman, The Leader, Leitrim Observer, Magill, New Review, New York Times, Ottawa Citizen, The Phoenix, Saothar, The Standard, The Star, Status, Sunday Business Post, Sunday Independent, Sunday Press, Sunday Tribune, Sunday World, Times Pictorial, Waterford Standard, Weekly Irish Times, West Australian (Perth)

\section{Academic journals}

Administration, Australian Journal of Politics and History, Crane Bag, Doctrine and Life, Furrow, Historical Research, Irish Broadcasting Review, Irish Communications Review, Irish Ecclesiastical Record, Irish Political Studies, Irish Studies Review, Irish University Review, Journal of the History of Sexuality, Journalism and Mass Communication Quarterly, Journalism Practice, Journalism Studies, Media History, New Hibernia Review, Studies

\section{Books}

Adams, Michael, Censorship: The Irish Experience (Tuscaloosa, Ala., 1968).

Ballin, Malcolm, Irish Periodical Culture, 1937-72: Genre in Ireland, Wales and Scotland (London, 2008).

Bance, Michael, Smokey Joe: The Life and Times of a Provincial Newspaper Editor (Dublin, 1994).

Bell, Desmond (ed.), Is the Irish Press Independent? Essays on Ownership and Control of the Provincial, National and International Press in Ireland (Dublin, 1986).

Bird, Charlie and Kevin Rafter, This Is Charlie Bird (Dublin, 2006).

Bowman, John, Window and Mirror: RTÉ Television, 1961-2011 (Dublin, 2011).

Brady, Conor, Up with the Times (Dublin, 2005).

Brown, Stephen, The Press in Ireland: A Survey and a Guide (Dublin, 1937).

Brown, Terence, The Irish Times: 150 Years of Influence (London, 2015).

Bundock, C. J., The National Union of Journalists: A Jubilee History, 1907-57 (Oxford, 1957).

Burke, Ray, Press Delete: The Decline and Fall of the Irish Press (Dublin, 2005).

Byrne, Gay, To Whom It Concerns: 10 Years of The Late Late Show (Dublin, 1972).

Clarke, Paddy, Dublin Calling: 2RN and the Birth of Irish Radio (Dublin, 1986).

Clear, Caitriona, Women's Voices in Ireland: Women's Magazines in the 1950s and 1960s (London, 2016).

Coogan, Tim Pat, A Memoir (London, 2008). 
Corcoran, Farrel, RTÉ and the Globalisation of Irish Television (Bristol, 2004).

Corcoran, Mary P. and Mark O'Brien (eds), Political Censorship and the Democratic State: The Irish Broadcasting Ban (Dublin, 2005).

Cronin, Anthony, No Laughing Matter: The Life and Times of Flann O'Brien (New York, 1998). Cullen, L. M., Eason \& Son: A History (Dublin, 1989).

Devane, R. S., The Imported Press: A National Menace - Some Remedies (Dublin, 1950).

Doolan, Lelia, Jack Dowling and Bob Quinn, Sit Down and Be Counted: The Cultural Evolution of a Television Station (Dublin, 1969).

Downey, James, In My Own Time: Inside Irish Politics and Society (Dublin, 2009).

Doyle-O'Neill, Finola, The Gaybo Revolution: How Gay Byrne Challenged Irish Society (Dublin, 2015).

Dungan, Myles, Mr Parnell's Rottweiler: Censorship and the United Ireland Newspaper, 1881-91 (Dublin, 2014).

Dunlop, Andrew, Fifty Years of Irish Journalism (Dublin, 1911).

Dunne, John J., Headlines and Haloes (Dublin, 1988).

Dunne, Joseph, No Tigers in Africa (Dublin, 1986).

Fahy, Tony and Mary Kelly (eds), The Role of the Media in Irish Society (Dublin, 1988).

Fanning, Bryan, The Quest for Modern Ireland: The Battle of Ideas, 1912-86 (Dublin, 2008).

Farrell, Brian (ed.), Communications and Community in Ireland (Dublin, 1984).

Fisher, Des, Broadcasting in Ireland (London, 1978).

Fleming, Lionel, Head or Harp (London, 1965).

Foley, Michael, Death in Every Paragraph: Journalism and the Great Irish Famine (Hamden, Conn., 2015).

Gayle Backus, Margot, Scandal Work: James Joyce, the New Journalism and the Home Rule Newspaper Wars (Notre Dame, Ind., 2013).

Gillespie, Elgy, Changing the Times: Irish Women Journalists, 1969-81 (Dublin, 2003).

Glandon, Virginia, Arthur Griffith and the Advanced Nationalist Press, Ireland, 1900-23 (New York, 1985).

Gopsill, Tim and Greg Neale, Journalists: 100 Years of the NUJ (London, 2007).

Gorham, Maurice, Forty Years of Irish Broadcasting (Dublin, 1967).

Gray, Tony, Mr Smyllie, Sir (Dublin, 1991).

Greene, Roger, Under the Spotlight: Conversations with 17 Leading Irish Journalists (Dublin, 2005).

Hall, John B., Random Records of a Reporter (Dublin, 1928).

Healy, John, Healy, Reporter: The Early Years (Achill, 1991).

Horgan, John, Irish Media: A Critical History since 1922 (London, 2001).

_-Broadcasting and Public Life: RTÉ News and Current Affairs, 1926-97 (Dublin, 2004).

- (ed.), Great Irish Reportage: Ground-breaking Irish Journalism, Eyewitness Accounts and Dispatches since 1922 (Dublin, 2013).

Horgan, John, Barbara O'Connor and Helena Sheehan (eds), Mapping Irish Media: Critical Explorations (Dublin, 2007).

Inglis, Brian, West Briton (London, 1962).

- Downstart (London, 1990).

James, Dermot, From the Margins to the Centre: A History of the Irish Times (Dublin, 2008).

Kelly, James, Bonfires on the Hillside (Belfast, 1995).

Kenneally, Ian, The Paper Wall: Newspapers and Propaganda in Ireland, 1919-21 (Cork, 2008).

Kennedy, Dennis, Square Peg: The Life and Times of a Northern Newspaperman South of the Border (Dublin, 2009). 
Kenny, David (ed.), The Press Gang: Tales from the Glory Days of Irish Newspapers (Dublin, 2015).

Kenny, Ivor, Talking to Ourselves: Conversations with Editors of the Irish News Media (Galway, 1994).

Kiberd, Damien (ed.), Media in Ireland: The Search for Diversity (Dublin, 1997).

- (ed.), Media in Ireland: The Search for Ethical Journalism (Dublin, 1999).

- (ed.), Media in Ireland: Issues in Broadcasting (Dublin, 2002).

Kilfeather, Frank, Changing Times: A Life in Journalism (Dublin, 1997).

Larkin, F. M., Terror and Discord: The Shemus Cartoons in the Freeman's Journal, 1920-24 (Dublin, 2009).

Legg, Maire-Louise, Newspapers and Nationalism: The Irish Provincial Press, 1850-92 (Dublin, 1999).

Lennon, Peter, Foreign Correspondent: Paris in the Sixties (London, 1994).

Lindsay, Paul (ed.), The Media and Modern Society in Ireland (Celbridge, 1993).

Mansfield, F. J., Gentlemen, The Press! Chronicles of a Crusade (London, 1943).

Martin, Peter, Censorship in the Two Irelands, 1922-39 (Dublin, 2006).

Martin, Séamus, Good Times and Bad (Dublin, 2008).

Matthews, Kelly, The Bell Magazine and the Representation of Irish Identity: Opening Windows (Dublin, 2012).

Maume, Patrick, D. P. Moran (Dundalk, 1995).

McCafferty, Nell, Nell (Dublin, 2004).

McDonnell Bodkin, Matthais, Recollections of an Irish Judge: Press, Bar and Parliament (London, 1914).

McLoone, Martin and John MacMahon (eds), Television and Irish Society: 21 Years of Irish Television (Dublin, 1984).

McRedmond, Louis (ed.), Written on the Wind: Personal Memories of Irish Radio, 1926-76 (Dublin, 1976).

Morash, Christopher, A History of the Media in Ireland (Cambridge, 2010).

Morrissey, Thomas, William Martin Murphy (Dundalk, 1997).

Mulryan, Peter, Radio Radio: The Story of Independent, Local, Community and Pirate Radio in Ireland (Dublin, 1988).

Myers, Kevin, Watching the Door: A Memoir (Dublin, 2006).

O'Brien, Mark, De Valera, Fianna Fáil and the Irish Press: The Truth in the News? (Dublin, 2001).

The Irish Times: A History (Dublin, 2008).

O'Brien, Mark and F. M. Larkin (eds), Periodicals and Journalism in Twentieth Century Ireland (Dublin, 2014).

O'Brien, Mark and Kevin Rafter (eds), Independent Newspapers: A History (Dublin, 2012).

O'Clery, Conor, May You Live in Interesting Times: Memoirs of a Foreign Correspondent (Dublin, 2008).

O’Donovan, Donal, Little Old Man Cut Short (Bray, 1998).

O Drisceoil, Donal, Censorship in Ireland, 1939-45, Neutrality, Politics and Society (Cork, 1996).

O'Reilly, Emily, Veronica Guerin: The Life and Death of a Crime Reporter (London, 1998).

O'Toole, Michael, More Kicks than Pence: A Life in Irish Journalism (Dublin, 1992).

Oram, Hugh, The Newspaper Book: A History of Newspapers in Ireland, 1649-1983 (Dublin, 1983).

— Paper Tigers: Stories of Irish Newspapers by the People Who Make Them (Belfast, 1993).

Orr, Charles, Splash! Drama and Comedy in a Newspaperman's Career (Braunton, 1989). 
Pine, Richard, 2RN and the Origins of Irish Radio (Dublin, 2002).

Purcell, Betty, Inside RTÉ: A Memoir (Dublin, 2014).

Rafter, Kevin (ed.), Irish Journalism before Independence: More a Disease than a Profession (Manchester, 2011).

Rafter, Kevin and Mark O'Brien (eds), The State in Transition: Essays in Honour of John Horgan (Dublin, 2015).

Reynolds, Paddy, The Late Paddy Murphy: Memoirs of an Irish Journalist (Belfast, 2004).

Ryan, Louise, Gender, Identity and the Irish Press, 1927-37: Embodying the Nation (New York, 2002).

Savage, Robert, Irish Television: The Political and Social Origins (Cork, 1996).

— A Loss of Innocence? Television and Irish Society, 1960-72 (Manchester, 2010).

Shovlin, Frank, The Irish Literary Periodical, 1923-58 (London, 2003).

Smith, Raymond, Urbi et Orbi and All That (Dublin, 1995).

Steele, Karen, Women, Press and Politics during the Irish Revival (Syracuse, NY, 2007).

Steele, Karen and Michael de Nie (eds), Ireland and the New Journalism (New York, 2014).

Uí Chollatáin, Regina, An Claidheamh Soluis agus Fáinne an Lae, 1899-1932 (Dublin, 2004).

Walsh, Maurice, The News from Ireland: Foreign Correspondents and the Irish Revolution (London, 2011).

Waters, John, Jiving at the Crossroads (Belfast, 1991).

Watson, Iarfhlaith, Broadcasting in Ireland: Minority Language, Radio, Television and Identity (Dublin, 2003).

Whittaker, Andrew (ed.), Bright Brilliant Days: Douglas Gageby and the Irish Times (Dublin, 2006).

Woodman, Kieran, Media Control in Ireland, 1923-83 (Galway, 1985). 